\title{
Student views on learning grammar with web- and book-based materials
}

\author{
Huw Jarvis and Marta Szymczyk
}

This paper reports on a study which examined students' attitudes to learning grammar in autonomous contexts and their preferences for the learning materials with which to do so. In all, 38 students were surveyed and 13 of these then spent some time working in a language resource centre $(L R C)$ with web-and paperbased materials. Students then completed a series of questionnaires concerning what they liked and disliked about the two types of materials. Four participants were then interviewed in more detail about their responses. The data suggest that despite the well-documented advantages of the tutorial role of computers and the notion of the 'digital native', participants generally preferred working with paperbased materials. The paper concludes with a discussion of the implications of this for materials that $L R C$ s stock and for the changing role of computers in self-study contexts.

Introduction

For many years, learner autonomy has been considered important and language resource centres (LRCs) and the materials that are stocked within them are frequently viewed as ideal physical locations to facilitate such autonomy. Centres will usually provide materials to cover the range of language skills as well as vocabulary, and arguably above all else, grammarbased materials. In a bygone era, such materials would be exclusively paperbased frequently comprising in-house task sheets and published self-study resource books. More recently, computers have come to play a significant role and in many contexts it would be difficult to imagine an LRC without computers.

It is against this background of change that a debate about the role of computers in the teaching and learning of grammar has emerged, a debate which has largely been discussed in terms of the advantages and limitations of computer-assisted language learning (CALL) as 'tutorial CALL' (Levy I997), in which the computer takes on a teaching function by providing corrections to exercises. Such tutorial CALL offers a number of opportunities for grammar practice. Like more traditional paper-based alternatives, the material allows for practice and production, both in the class and beyond, in fairly controlled situations. With websites now being the primary delivery mode, frequently available at no cost, the resource can be seen as providing 'anywhere, anytime' learning material. Such websites would seem then to ideally match the needs of our 'digital native students' (Prensky 200I) who have known nothing but digitalized technologies 
throughout their lives. Tutorial CALL is viewed by some as a dated application and one which is associated with a bygone era of Skinner (I954) and behaviourism, and as such, it is sometimes characterized as 'drill and kill' because students would mechanically input answers into a computer software program over and over again until they got it right. Recently, however, we have seen a renewed interest in, and an evaluation of, its role. In a key publication, Levy and Stockwell (2006: I85) note that 'Although a highly valid and useful application of CALL, drill based grammar activities, which comprise a significant proportion of grammar tutorial exercises, appear to have been the target of criticism in recent years ... '. They go on to suggest that 'Drill-based activities most certainly still have their place in the language curriculum'. The work of Hubard and Siskin (2004: 495) sets out to identify and then dispel a number of myths. They conclude that '. . . it is still a valuable part of CALL and deserves serious attention rather than summary dismissal'.

We have already noted the digital native, but there have been at least two other arguments which have been put forward to support tutorial C A L L over and above paper-based alternatives. Firstly, with its instant (albeit sometimes limited) feedback, it is seen as being particularly helpful in developing learner autonomy. Jarvis (2008: 369), however, characterizes such links as both well established and problematic:

They are well-established in that it is a commonly held view that the two go together ... The links are problematic, however, in that there is little in the literature which examines what students actually do in such centres and why; empirical data on the practices and perceptions of learners is noticeably missing ...

Secondly, tutorial CALL's motivational value has, over many years, been considered significant. It was over ten years ago that Carrier (I997: 280) observed that 'if we have learned anything from ten years of CALL experiments and lesson development, it is this: computer lessons are motivating ...' whilst Garcia and Arias (2000: 457) assert that their study '... proves that computers enhance motivation and effective learning'.

Given the importance of grammar in independent study, the wellestablished role of tutorial CALL, the notion of the digital native, and the proliferation of both web- and paper-based resource books, it is perhaps rather surprising that there have been few studies which compare such resources from the perspective of the learner. This study attempts to address this shortfall. In doing so, it helps teachers by identifying what students think of such self-study materials, it also better informs schools, colleges, and universities about the types of materials to stock in their resource centres. Additionally, the findings contribute to an ongoing debate about the role of computers for self-study in language pedagogy.

The study

Our primary questions were as follows:

- What attitudes do students have towards learning grammar outside the classroom?

- Do students prefer websites or paper-based self-study resource books to learn grammar outside the classroom? 
Methodology, materials, and participants
- What is the motivational impact of websites and paper-based self-study resource books for learning grammar outside the classroom?

Data were gathered using a variety of quantitative and qualitative techniques. The former were used to explore 'the measurement and analysis of causal relationships between variables, not processes' whilst the latter allowed for a focus on 'processes and meanings that are not rigorously examined, or measured in terms of quantity, amount, intensity, or frequency' (Denzin and Lincoln I998: 8). During the first phase of the study, participants were asked to fill in a short questionnaire about themselves and their attitudes towards learning grammar (Appendix I). The second stage of the study, which will be referred to as 'the tasks', aimed at comparing two different materials for independent grammar practice: a free website and a traditional self-study book. These were selected as typical representations of what is currently available with a design and approach which emphasizes 'two predominant methodological features: the provision of descriptions of grammatical points and controlled production exercises' (Ellis 2002: I76) - the primary difference between the materials lies in the medium of delivery and the feedback (automated for the websites). For web-based materials, we used:

- http://www.english-4u.de/grammarr.htm

- http://www.englishclub.com/grammar/verb-tenses_presentperfect.htm

For paper-based self-study resource book publications, we used: Murphy (2004) and Vince and Emmerson (2006).

Before working on any of the materials, the participants had in the first phase of the study already expressed a preference for paper-based material, but in order to make more meaningful comparisons and arrive at their reasoning, we asked them to work on both sets of materials in an LRC which was done out of class time. First of all, the participants spent 30 minutes practising grammar on a free website after which they completed a questionnaire (Appendix 2). Second, the participants spent another 30 minutes practising grammar from a popular self-study book and again completed a questionnaire (Appendix 3). Finally, students were given a questionnaire which compared both sets of materials (Appendix 4). A final phase of the study comprised semi-structured interviews.

The first phase of the study involved 38 non-native speakers (N N Ss) of English between the ages of I7 and 52 years from Jordan, Morocco, Dominican Republic, Taiwan, Thailand, Saudi Arabia, Greece, the People's Republic of China, Cyprus, Libya, Vietnam, United Arab Emirates, and Turkey. All of them were enrolled on a pre-sessional EAP (English for Academic Purposes) programme at a British University, and as such, all would be going on to further academic study in English upon successful completion of their course. The participants can thus be regarded as having high extrinsic motivation. However, of these, 30 out of the 38 declared that they actually spent time on studying grammar outside the classroom, and it is this figure which is used in discussing this stage of the study. Their level of English varied from pre-intermediate to upper-intermediate, as measured 
Limitations

\section{Results}

Grammar practice outside the classroom by an internal placement test. These levels correlate to an IE LTS banding of between 4.5 and 7. Variables of age, country of origin, and level of English proficiency were examined but were not found to be statistically significant and are, therefore, not reported here. The second phase of the study consisted of tasks which involved I3 participants who were selected on the basis of a willingness to take part and who were available at a time when it was possible to book a computer room. The final, semi-structured interview phase comprised four participants who were selected on the basis of representing a cross-section of views and had expressed a willingness to take part. The interviews were set up at a time and in a place to suit the participants and were then recoded and transcribed.

We acknowledge a number of limitations. Arguably, the most significant is concerned with, what Dörnyei (200I: I6) calls 'the challenge of time'. Although many theorists consider motivation as a relatively stable state, it usually evolves gradually and does not remain constant throughout a longer period of time. This study simply provides a snap shot of students' attitudes towards the materials at a particular time. Therefore, the results cannot be used to generate statements that account for different subphases of motivation that are likely to emerge with time. This is an area of further research. Secondly, for logistical reasons, the choice of materials for independent grammar practice was fairly restrictive. We do, however, consider the material to be typical of what is out there in terms of websites which deliver tutorial CALL and paper-based materials in the form of published self-study books. Finally, small samples were used and we acknowledge that further work might usefully draw upon a larger sample from a wider range of contexts as well as more intensive qualitative techniques such as observations of students working on materials. Despite these limitations, we consider that the data gathered provide us with some valuable insights into this under-explored area.

In general, participants considered grammar practice a very important aspect of language learning. For over half of them (2I students), grammar practice was of great importance. In addition, I3 students considered grammar practice of very great importance and four thought that it had some importance in language learning. Despite its recognized significance, attitudes towards grammar differed. Figure I illustrates how the students completed the sentence: Grammar practice is ......... for me.

With regard to practising grammar independently, 30 out of 38 students declared that they spent time on studying grammar outside the classroom. Eight students reported not practising grammar independently and they provided a variety of reasons for this: lack of time (two students), because it is boring (two students), practising grammar only with a teacher during an English course (one student), practising other aspects of English such as vocabulary (one student), lack of results (one student), grammar being difficult to practise (one student). These reasons are consistent with literature suggestions regarding problems encountered while learning grammar (Fortune 1992). 
FIGURE 1

Students' opinions about grammar practice.

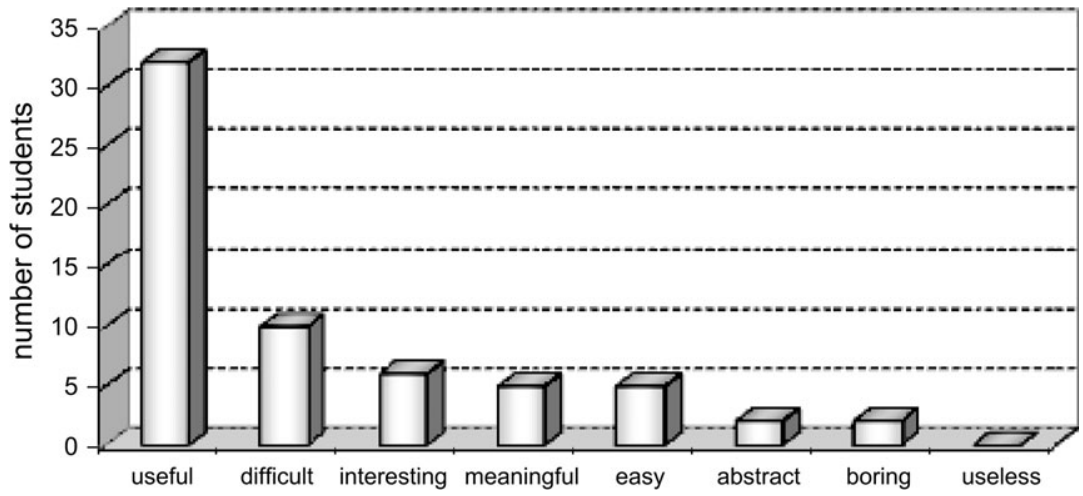

Our subsequent discussion of data is drawn from the 30 respondents who stated that they practised grammar independently. Regarding the amount of time spent on independent grammar practice, ten declared that they practised grammar once a week, seven two/three times a week, and six more than three times a week. Seven students stated that they practised grammar independently less than once a week. These numbers, however, should not be treated as definite. It is clear from the interviews that the amount of time devoted to independent grammar practice usually depends on a number of variables. The following comments from Interviews II and IV illustrate this:

Interview II: When I meet a problem of grammar I will check the information and practise.

Interview IV: Usually, [I practise grammar] twice a week. But it depends ... sometimes, for example, when I have test I practise more and sometimes not so often. It depends. But usually twice a week, yes.

Nevertheless, the majority of students appear to practise grammar at least once a week which seems to be due to grammar accuracy being considered an important part of general linguistic competence. The view from Interview II supports this argument: 'If your grammar is wrong it's difficult for you to communicate with others. And it's difficult for others to understand ... when you communicate you will meet difficulties where is a problem of grammar. You must speak correctly'.

Let us turn now to the data concerning students' choices of self-study grammar materials. Figure 2 illustrates the frequency with which students use the two types of materials.

There is a clear preference for self-study resource book material over and above websites and the task phase of the study gives us some insights into the reasons for this.

This section of the study generated considerable data and the total numbers are documented in full in Appendices 2, 3, and 4. Here we will discuss the most significant findings. 
FIGURE 2

Self-study grammar materials-frequency of use.

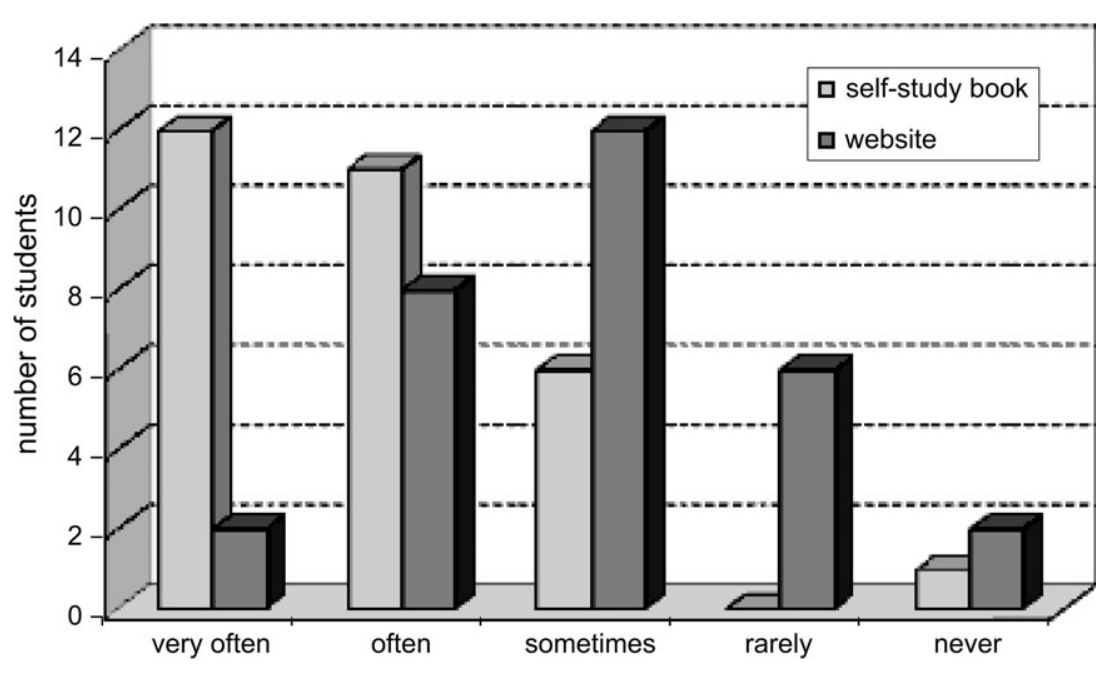

The questionnaire data show clearly that in comparison with websites, the self-study books were viewed more positively and this provides a degree of triangulation to the frequency findings reported in the first part of the study - one would expect students to report more positively on the materials that they chose to work with more frequently. We see that with learning grammar using websites (Appendix 2, I.I) there is a fair degree of distributed responses across four categories of 'strongly agree', 'agree', 'uncertain', and 'disagree'. At the two extremes, the 'strongly agree' box is selected a total of 15 times and the 'disagree' box is selected 24 times across the ten criteria. For the same ten criteria with learning grammar using a selfstudy book (Appendix 3, I.I), we see a lesser degree of distributed responses and a more positive tendency across the categories, here the 'strongly agree' box is selected a total of 34 times and the 'disagree' box only twice. A similar trend is evident with material design; here, at the two extremes, we can note that six students selected 'strongly agree' for at least one of the six criteria for websites (Appendix 2, I.2) compared to 34 for self-study books (Appendix 3 , I.2) and at the other end of the scale, I4 selected 'disagree' compared to two, respectively. The materials comparison data (Appendix 4) provide further evidence of a preference for self-study books. The open-ended question about difficulties experienced at the end of Appendices 2 and 3 offers little insight into the reasons, with seven and ten participants (out of I2) simply answering 'no'.

The semi-structured interviews, however, do give some insights. Student I stressed the importance of order (sequence), as found in the book, and seemed perturbed by hypertext 'sometimes the internet direct me ... and I find myself in other pages in other subject I don't' like it'. Student II expressed a similar view when commenting on the differences between the books and the websites, books were 'very systematic ... On the internet I think the materials are of various-sometimes it's very interesting but not as systematic'. Whilst Student I I I notes that ' $\ldots$ you can take books with you everywhere' a similar point is made by Student IV who 
reports that '. . books are always available. I mean you can get them and take them almost everywhere. For me it's important because I practise in many places'.

\section{Discussion}

Conclusion
The study suggests that, in general, students had positive attitudes towards learning grammar independently, considered grammar practice a vital part of foreign language learning, and that they used a variety of materials for this purpose. The data revealed that students' attitudes towards the self-study book were more positive and that they considered the paper-based material more useful for independent grammar practice than the computer-based counterparts. According to students, among the advantages of self-study books, we can distinguish: availability, clear organization and gradation of exercises, comprehensible presentation and explanation of a grammar point, and clarity of instructions. The biggest limitation, on the other hand, seems to be lack of variety which makes independent grammar practice with a book boring. Regarding the computer-based material evaluation, whilst it cannot be concluded that students' feedback was negative, nonetheless the level of uncertainty was much higher. Students' perception of practising grammar on the Web was generally positive but according to them such practice also had more disadvantages. Insufficient computer skills seem to prevent many students from choosing computer-based materials for grammar practice. Moreover, a lack of systematic organization of materials tends to be perceived as a limitation. As far as advantages of computer-based materials are concerned, the biggest one seems to be variety. Many students emphasized the fact that the websites, unlike any other material, provided them with a vast amount of activities which made grammar practice more interesting.

This study suggests that despite the era of the digital native, our students have not, under certain circumstances, abandoned more traditional resources and it would be a mistake for practitioners and other resource providers to slavishly follow the digitalized medium route for everything. The $24 / 7$ access argument, which is sometimes used to dismiss traditional alternatives, has been turned on its head in this study; it is an argument which was used by this small sample in support of paper-based resources. LRC providers clearly need to stock a wide range of paper-based resource materials alongside CALL alternatives. Furthermore, the potential opportunities offered by a blended approach which combines both digitalized and paper-based materials should not be overlooked and the implications for LRC design need to be addressed. All too frequently LRCs seem to be driven by and designed for digitalized resources which fail to allow for students to work with computers and paper-based resources; workspace is often equated with little more than space for a keyboard and a mouse.

We conclude that the tutorial CA L L has a role but shows no sign of replacing paper-based materials. Furthermore, we draw on a parallel study (in the same LRC) to assert a less restrictive role for computers in such contexts. There is some evidence (Jarvis 2008) to suggest that N NSs view a wide range of computer materials as helping with their language studies even 
where there is no explicit language learning function such as working on assignments, sending an email, or accessing information from the Web. Students clearly do recognize a role for tutorial CA LL, but equally they do not prefer it to resource-based books. Indeed, arguably, today the primary role of computers in self-study contexts is as a medium of communication. The 'assisting language learning' function is just one of many, with accessing and communicating information functions probably being of greater importance. This in turn gives rise to new e-literacy challenges such as assessing the validity of websites or the conventions of writing emails, etc. (see, for example, Jarvis and Pastuszka 2008). Despite a changed context of the widespread availability of computers, a good old-fashioned self-study grammar book still has an important place for our learners.

Revised version received December 2008

\section{References}

Carrier, M. I997. 'E LT online: the rise and rise of the Internet'. E LT Journal 51/3: 279-301.

Denzin, N. K. and Y. S. Lincoln. (eds.). I998. Collecting and Interpreting Qualitative Materials. London: Sage.

Dörnyei, Z. 200I. Teaching and Researching Motivation. Harlow, UK: Longman.

Ellis, R. 2002. 'Methodological options in grammar teaching materials' in E. Hinkel and S. Fotos (eds.). New Perspectives on Grammar Teaching in Second Language Classrooms. Mahwah, NJ: Lawrence Erlbaum Associates.

Fortune, A. I992. 'Self-study grammar practice: learners' views and preferences'. ELT Journal 46/2: i6o-7i.

Garcia, M. and F. Arias. 2000. 'A comparative study in motivation and learning through print-orientated and computer orientated tests'. Computer Assisted Language Learning I3/4-5: 457-65.

Hubard, P. and C. Siskin. 2004. 'Another look at tutorial CA LL'. ReCall I6/2: 448-6r.

Jarvis, H. 2008. 'Computers and independent study: practices and perceptions of students' in P. Torres and R. Marriott (eds.). Handbook of Research on E-Learning Methodologies for Language Acquisition. Hershey, PA: Information Science Reference. Jarvis, H. and L. Pastuszka. 2008. 'Electronic literacy, reading skills and non-native speakers: issues for EAP'. CALL-EJ Online 1о/r. Available online at http://www.tell.is.ritsumei.ac.jp/callejonline/ journal/IO-I/jarvis.html. Date accessed I5 August 2008.

Levy, M. I997. Computer-Assisted Language Learning: Context and Conceptualization. Oxford: Oxford University Press.
Levy, M. and G. Stockwell. 2006. CA LL Dimensions. Mahwah, NJ: Lawrence Erlbaum Associates.

Murphy, R. 2004. English Grammar in Use: A Selfstudy Reference and Practice Book for Intermediate Students of English (3rd edn.). Cambridge: Cambridge University Press.

Prensky, M. 200I. 'Digital natives, digital immigrants'. On the Horizon 9/5, М С В University Press. Available online at http.//www.marcprensky. com/writing/Prensky\%20-\%2oDigital\%2oNatives, \%20Digital\%2oImmigrants\%20-\%20Parti.pdf. Date accessed I5 January 2008.

Skinner, B. F. I954. 'The science of learning and the art of teaching. Harvard Educational Review 24/I: 86-97.

Vince, M. and P. Emmerson. 2006. Intermediate Language Practice. Oxford: Macmillan.

\section{The authors}

Huw Jarvis is a Senior Lecturer in E LT at the University of Salford in the UK. He has 25 years experience as a language teacher and trainer and has worked with teachers in Sudan, Kuwait, Thailand, Malaysia, the People's Republic of China, and Taiwan. He is the webmaster and editor of www.tesolacademic.org which is a site dedicated to the linking of theory and practice in TE S O L-based educational research through a series of video clips Email: H.A.Jarvis@salford.ac.uk

Marta Szymczyk has worked as an English teacher in Poland for a number of years. She recently completed her MA in TEF L at the University of Salford. 
Appendix 1

Grammar questionnaire
I GENERAL INFORMATION

I How old are you?

2 Where are you from?

3 How would you describe your computer skills? (tick only one)

$\square$ I am an excellent computer user. $\quad \square \quad$ I am not a good computer user.

I am a good computer user. $\quad \square \quad$ I am a poor computer user.

\section{INDEPENDENT GRAMMAR PRACTICE}

4 Complete the sentence. Grammar practice is ....... for me. (tick as many answers as apply to you)
$\square$ easy boring
useful
useless
$\square$ abstract
meaningful
difficult interesting

5 How important is grammar practice in language learning to you? (tick only one)
$\square$ of very great importance
$\square$ of some importance
of great importance
$\square$ of no importance

6 Do you practise grammar independently? (tick only one) $\square$ yes $\quad \square$ no If yes go to question 8. If no go to question 7 .

7 Why don't you practise grammar independently?

8 How often do you practise grammar independently? (tick only one) $\square$ less than once a week $\square$ two/three times a week $\square$ once a week more than three times a week

9 What kind of materials do you use for independent grammar practice and how often do you use each of them? (tick all the answers that apply to you)

\begin{tabular}{lll}
\hline $\begin{array}{l}\text { Type of material/ } \\
\text { frequency of use }\end{array}$ & Very often Often Sometimes Rarely Never \\
\hline
\end{tabular}

\section{Self-study books}

Free websites for practising English

Are you willing to take part in the next stage of the study (short grammar activities and questionnaires in the LRC)?

I am willing to take part

I am not willing to take part 
Please write your name and email or telephone number if you are willing to participate. Note that all information will be treated as confidential and you will not be personally named in any reported findings.

My name is

Tel. no

Email

Thank you for finding the time to complete this questionnaire.

\section{Appendix 2}

The task: questionnaires WEB S ITE EVALUATION

(Presented with collated data)

1 Please think about the material that you have just used and tick ( $\mathscr{}$ ) the sentences which apply to you.

\section{I.I LEARNING GRAMMAR}

\begin{tabular}{lllllll}
\hline $\begin{array}{l}\text { The material ... } \\
\text { agree }\end{array}$ & $\begin{array}{l}\text { Strongly } \\
\text { agree }\end{array}$ & Uncertain & Disagree & $\begin{array}{l}\text { Strongly } \\
\text { disagree }\end{array}$ \\
\hline $\begin{array}{l}\text { a was appropriate to my } \\
\text { age and level. }\end{array}$ & 1 & 6 & 3 & 3 & 0 \\
\hline $\begin{array}{l}\text { b was appropriate to my } \\
\text { needs. }\end{array}$ & 1 & 6 & 3 & 3 & 0 \\
\hline $\begin{array}{l}\text { c provided me with } \\
\text { enough practice. }\end{array}$ & 4 & 5 & 2 & 2 & 0 \\
\hline $\begin{array}{l}\text { d presented a grammar } \\
\text { point in a clear and } \\
\text { interesting way. }\end{array}$ & 1 & 7 & 2 & 3 & 0 \\
\hline $\begin{array}{l}\text { e contained a clear and } \\
\text { sufficient explanations of } \\
\text { the grammar point. }\end{array}$ & 0 & 9 & 2 & 2 & 0 \\
\hline $\begin{array}{l}\text { f presented and practised } \\
\text { grammar structure in } \\
\text { isolation (not in the text). }\end{array}$ & 0 & 12 & 0 & 1 & 0 \\
\hline $\begin{array}{l}\text { g contained a variety of } \\
\text { interesting activities. }\end{array}$ & 0 & 8 & 2 & 3 & 0 \\
\hline $\begin{array}{l}\text { h was clearly organized } \\
\text { and graded. }\end{array}$ & 4 & 6 & 2 & 1 & 0 \\
\hline $\begin{array}{l}\text { i provided me with examples } \\
\text { and explanations of how to } \\
\text { use the structure in different } \\
\text { situations. }\end{array}$ & 2 & 5 & 2 & 3 & 1 \\
\hline $\begin{array}{l}\text { j stressed the importance } \\
\text { of using the structure } \\
\text { correctly at all times. }\end{array}$ & 2 & 6 & 2 & 3 & 0 \\
\hline
\end{tabular}




\begin{tabular}{|c|c|c|c|c|c|}
\hline The material ... & $\begin{array}{l}\text { Strongly } \\
\text { agree }\end{array}$ & Agree & Uncertain & Disagree & $\begin{array}{l}\text { Strongly } \\
\text { disagree }\end{array}$ \\
\hline a contained attractive visuals. & 0 & 7 & 2 & 3 & 1 \\
\hline $\begin{array}{l}\text { b had clear and attractive } \\
\text { screen layout/design. }\end{array}$ & 1 & 9 & 2 & 1 & 0 \\
\hline $\begin{array}{l}\text { c used sound and visuals } \\
\text { effectively to support } \\
\text { grammar presentation } \\
\text { and practice (e.g. highlight } \\
\text { important points). }\end{array}$ & 0 & 4 & 4 & 4 & 1 \\
\hline $\mathrm{d}$ was easy to use (navigate). & 1 & 11 & 1 & 0 & 0 \\
\hline $\begin{array}{l}\text { e provided on-screen help } \\
\text { (available at all times). }\end{array}$ & 1 & 6 & 2 & 4 & 0 \\
\hline $\begin{array}{l}\text { f had clear instructions to } \\
\text { all the activities. }\end{array}$ & 3 & 5 & 3 & 2 & 0 \\
\hline
\end{tabular}

2 Did you experience any difficulties while using the material? Specify.

\section{Appendix 3}

The task: questionnaires BOOK EVALUATION

(Presented with collated data)

1 Please think about the material that you have just used and tick ( $\mathscr{}$ ) the sentences which apply to you.

\section{I.I LEARNING GRAMMAR}

\begin{tabular}{lllllll}
\hline $\begin{array}{l}\text { The material ... } \\
\text { agree }\end{array}$ & $\begin{array}{l}\text { Strongly } \\
\text { agree }\end{array}$ & Uncertain & $\begin{array}{c}\text { Disagree } \\
\text { Strongly } \\
\text { disagree }\end{array}$ \\
\hline $\begin{array}{l}\text { a was appropriate to my } \\
\text { age and level. }\end{array}$ & 4 & 7 & 1 & 1 & 0 \\
\hline b was appropriate to my needs. & 1 & 11 & 1 & 0 & 0 \\
\hline $\begin{array}{l}\text { c provided me with enough } \\
\text { practice. }\end{array}$ & 5 & 7 & 1 & 0 & 0 \\
\hline $\begin{array}{l}\text { d presented a grammar point in } \\
\text { a clear and interesting way. }\end{array}$ & 4 & 7 & 2 & 0 & 0 \\
\hline $\begin{array}{l}\text { e contained a clear and } \\
\text { sufficient explanation } \\
\text { of the grammar point. }\end{array}$ & 6 & 6 & 1 & 0 & 0 \\
$\begin{array}{l}\text { f presented and practised } \\
\text { grammar structure in } \\
\text { isolation (not in the text). }\end{array}$ & 3 & 9 & 1 & 0 & 0 \\
\hline
\end{tabular}


g contained a variety of

1
interesting activities.

\begin{tabular}{llllll}
\hline $\begin{array}{l}\text { h was clearly organized } \\
\text { and graded. }\end{array}$ & 3 & 9 & 1 & 0 & 0 \\
\hline $\begin{array}{l}\text { i stressed the importance } \\
\text { of using the structure correctly } \\
\text { at all times. }\end{array}$ & 3 & 10 & 0 & 0 & 0 \\
\hline $\begin{array}{l}\text { provided me with } \\
\text { examples and explanation } \\
\text { of how to use the structure } \\
\text { in different situations. }\end{array}$ & 4 & 7 & 2 & 0 & 0 \\
\hline
\end{tabular}

\section{I.2 MATERIAL DESIGN}

\begin{tabular}{|c|c|c|c|c|c|}
\hline The material ... & $\begin{array}{l}\text { Strongly } \\
\text { agree }\end{array}$ & Agree & Uncertain & Disagree & $\begin{array}{l}\text { Strongly } \\
\text { disagree }\end{array}$ \\
\hline a contained attractive visuals. & 0 & 7 & 2 & 4 & 0 \\
\hline $\begin{array}{l}\text { b had clear and attractive } \\
\text { page layout/design. }\end{array}$ & 1 & 11 & 1 & 0 & 0 \\
\hline $\begin{array}{l}\text { c used visuals effectively } \\
\text { to support grammar } \\
\text { presentation and practice } \\
\text { (e.g. highlight important } \\
\text { points). }\end{array}$ & 0 & 9 & 2 & 2 & 0 \\
\hline $\mathrm{d}$ was easy to use. & 6 & 7 & 0 & 0 & 0 \\
\hline $\begin{array}{l}\text { e had clear instructions } \\
\text { to all the activities. }\end{array}$ & 4 & 7 & 2 & 0 & 0 \\
\hline $\begin{array}{l}f \text { contained units of } \\
\text { appropriate length. }\end{array}$ & 1 & 10 & 2 & 0 & 0 \\
\hline
\end{tabular}

2 Did you experience any difficulties while using the material? Specify.

\section{Appendix 4}

Materials comparison (Presented with collated data)

1 Please think about the two materials that you have just used and tick ( answers that apply to you.

\begin{tabular}{llllll}
\hline & $\begin{array}{l}\text { Strongly } \\
\text { agree }\end{array}$ & Agree & Uncertain & $\begin{array}{r}\text { Disagree } \\
\end{array}$ & $\begin{array}{r}\text { Strongly } \\
\text { disagree }\end{array}$ \\
\hline a I feel confident about & 7 & 5 & 1 & 0 & 0 \\
$\begin{array}{l}\text { using the self-study book } \\
\text { for independent grammar } \\
\text { practice. }\end{array}$ & & & & & \\
\hline
\end{tabular}


b I feel confident about

1

8

4

0

0 using the website for independent grammar practice.

\begin{tabular}{|c|c|c|c|c|c|}
\hline $\begin{array}{l}\text { c I found the self-study } \\
\text { book useful and effective } \\
\text { for independent grammar } \\
\text { practice. }\end{array}$ & 9 & 4 & 0 & 0 & 0 \\
\hline $\begin{array}{l}\mathrm{d} \text { I found the website } \\
\text { useful and effective for } \\
\text { independent grammar } \\
\text { practice. }\end{array}$ & 3 & 7 & 2 & 1 & 0 \\
\hline $\begin{array}{l}\text { e I found the self-study } \\
\text { book easy to use as a whole. }\end{array}$ & 9 & 4 & 0 & 0 & 0 \\
\hline $\begin{array}{l}f \text { I found the website } \\
\text { easy to use as a whole. }\end{array}$ & 3 & 6 & 4 & 0 & 0 \\
\hline $\begin{array}{l}\text { g Practising grammar using } \\
\text { a self-study book was a } \\
\text { positive learning experience. }\end{array}$ & 7 & 6 & 0 & 0 & 0 \\
\hline $\begin{array}{l}\text { h Practising grammar using } \\
\text { the website was a positive } \\
\text { learning experience. }\end{array}$ & 3 & 6 & 4 & 0 & 0 \\
\hline $\begin{array}{l}\text { i I am motivated to use } \\
\text { self-study books for } \\
\text { independent grammar } \\
\text { practice in the future. }\end{array}$ & 6 & 7 & 0 & 0 & 0 \\
\hline $\begin{array}{l}\text { j I am motivated to use } \\
\text { websites for independent } \\
\text { grammar practice in the future. }\end{array}$ & 4 & 5 & 4 & 0 & 0 \\
\hline
\end{tabular}

2 Which of the materials did you find most useful for practising grammar? (tick only one)

$\square$ self-study book

$\square$ free website for practising English

3 Give reasons for your choice.

Thank you for finding the time to complete these questionnaires. 